\title{
Relationship between Family Socio-Economic Status and The Incidence of Stunting Among Children Aged 24-59 Months in The Work Area of Kadipaten Community Health Center Majalengka District in 2019
}

\author{
Rina Nuraeni ${ }^{*}$ and Suharno Suharno ${ }^{b}$ \\ Lecturer in Nursing, STIKes YPIB Majalengka, West Java Indonesia \\ arinasyifa79@gmail.com, bharnoamazing@gmail.com \\ *Correspondence: rinasyifa79@gmail.com \\ Type of the Paper (Article)
}

Received: October 28, 2020; Accepted: December 22, 2020; Published: March 14, 2021 https://doi.org/10.29253/achnr.2020.21652

\begin{abstract}
The incidence of stunting among children, especially under-five children is still high. At the Kadipaten CHC in 2019 there were $4.6 \%$ under-five children with stunting. This study aims to determine the relationship between socio-economic status and the incidence of stunting among children aged 2459 months in the Work Area of Kadipaten Community Health Center, Majalengka District in 2019. This was a quantitative study with a cross-sectional design. The samples in this study were 328 children and parents of children aged 24-59 months in the work area of Kadipaten CHC, Majalengka District taken with simple random sampling technique. This study was conducted from February - July 2020. Data were analyzed using univariate analysis with frequency distribution and bivariate analysis with chisquare test. The results showed that among children aged 24-59 months in the Work Area of Kadipaten Community Health Center, Majalengka District in 2019, 11.3\% experienced stunting, 36.6\% had families with socio-economic status below the Regional Minimum Wage/UMR, and there was a significant relationship between socio-economic status of the family and the incidence of stunting in the Work Area of Kadipaten Community Health Center, Majalengka District in 2019 ( $\mathrm{r}$ value $=0.02$ ). CHC should collaborate with cadres in conducting health education about stunting and collaborates with related agencies to provide skills training for families whose income is below the UMR, so that they are able to create new businesses and increase family income. This is expected to affect the pattern of meeting family nutritional requirements.
\end{abstract}

Keywords: socio-economic status; stunting; children aged 24-59 months

\section{Introduction}

Children's health plays an important role in the healthy development of a nation because children are the nation's future generations. The effort to present this golden generation is overshadowed by the threatening stunting problem. Stunting refers to the height of a child that is shorter than the normal 
height of his age. Stunting occurs due to chronic malnutrition during the first 1,000 days of life (MoH of the Republic of Indonesia, 2017).

Nutritional problems in children need to be managed appropriately because of the potential for high mortality rates. According to the 2018 Global Nutrition Report, there were 150.8 million (22.2\%) underfive children who experienced stunting in the world (Indonesian Ministry of Health, 2019). Indonesia is one of the countries with the fifth highest stunting incidence in the world. Of the number of under-five children in the world as many as 195.1 million, India is the country with the highest incidence of stunting, namely 60,788 cases $(31.2 \%)$, followed by China with 12,685 cases $(6.5 \%)$, Nigeria with 10,158 cases (5.2\%), Pakistan 9,868 cases (5.1\%), then Indonesia with a total of 7,688 cases (3.9\%) (MoHof the Republic of Indonesia, 2019).

The results of the Basic Health Research in 2018 showed that the prevalence of stunting in the national scope was $30.8 \%$, consisting of a stunting prevalence of $19.3 \%$ and a very short prevalence of $11.5 \%$. Meanwhile in 2017, the prevalence of stunting in Indonesia was $29.0 \%$, consisting of a stunting prevalence of $19.8 \%$ and a very short prevalence of $9.8 \%$. This indicated that the incidence of stunting among under-five children in Indonesia in 2017-2018 increased by 1.8\% and became a serious public health problem because the prevalence of stunting in Indonesia was in the 30-39 percent range (Indonesian Ministry of Health, 2019). Whereas in West Java Province in 2018, 11.70\% under-five children who experienced very short stunting and $19.40 \%$ were short and in $20178.40 \%$ children experienced very short stunting and $20.80 \%$ were short (West Java Provincial Health Office, 2018).

Based on data derived from the Majalengka District Health Office in 2019, out of a total of 88,139 toddlers, 3,905 under-five children (4.43\%) experienced stunting and $737(0.84 \%)$ were very short children. Whereas in 2018, there were 1,958 toddlers (2.19\%) who experienced stunting. This meant that the incidence of stunting among under-five children in Majalengka District increased by $2.24 \%$, from 2.19\% to 4.43\% in 2018 (Majalengka District Health Office, 2019).

Based on the reports on the Monthly Weighing for Under-five children in the work area of Kadipaten CHC in 2018, it was revealed that 17 children aged 24-59 months were stunted from a total of 3262 under-five children measured. Liangjulang Village had the highest prevalenceof stunting (Data for Monthly Weighing for Under-five children in the work area of Kadipaten CHC, 2018). And in 2019 there were $4.6 \%$ stunted toddlers (Data for Monthly Weighing for Under-five children in the work area of Kadipaten CHC, 2019).

Under Five Years (toddler) is one of the periods of human age after an infant with an age range starting from two to five years. It consists of two groups, namely the toddler age and preschool age. At the toddler age, namely the age of 1-3 years, a child begins to learn to determine the direction of his own development, a phase that underlies the degree of health, emotional development, educational level, selfconfidence, social skills and the ability of a child in the future. Meanwhile,at the preschool age, namely 46 years old, children are undergoing a very rapid growth and development process, so they need intensive stimulation from those around them in order to have a quality personality in the future (Sudiaoetama, 2015).

The incidence of stunting amongunder-five children can cause various impacts or losses. The loss due to stunting for the government is the increase in spending for national health insurance related to non-communicable diseases such as heart disease, stroke, diabetes or kidney failure. In adulthood, children who ever experienced stunting are prone to obesity, so they are vulnerable to noncommunicable diseases such as heart disease, stroke or diabetes (MoH of the Republic of Indonesia, 2019).

The incidence of stunting can continue to increase if there aremany unknown risk factors for stunting in an area. This can result in difficulty in preventing early incidence of chronic malnutrition. Chronic malnutrition is not only caused by one factor but caused by many factors, and these factors are interrelated with one another. There are three main causes of stunting, namely unbalanced food intake, history of low birth weight, and history of disease (Wiyogowati, 2010).

The problem of stunting in children under five needs serious attention since it may cause losses to the government, it also has adverse effects both in the short and long term. According to the Indonesian Ministry of Health (2017), the adverse effects of stunting in the short term include disruption in brain development, intelligence, physical growth disorders, and metabolic disorders in the body. Meanwhile, the adverse effectsof stunting in the long term include decreased cognitive abilities and learning 
achievement, decreased immunity so that they get sick easily, and a high risk of diabetes, obesity, heart and blood vessel disease, cancer, stroke, anddisabilities later in old age.

There are many factors that cause the incidence of stunting among children aged 1-5 years. According to the Indonesian Ministry of Health (2017), the causal factors for stunting are malnutrition experienced by pregnant women and under-five children, the lack of maternal knowledge about health and nutrition before and during pregnancy, limited health services including antenatal care services, lack of access to nutritious food and lack of access to clean water and sanitation. Meanwhile, according to Aridiyah, Rohmawati and Ririanty (2015), the determinant factor of stunting was dietary factors such as energy, protein and zinc intake. Meanwhile, the risk factors for stunting could be due to family income, number of family members, maternal education, maternal knowledge, history of breastfeeding, birth weight and completeness of immunization.

Family socio-economic status is described by family income which is also the main determinant related to food quality. If the family income increases, the quality of the side dishes will also increase. It cannot be denied that family income will determine the dishes served for the family on a daily basis, both regarding the quality and quantity of food (Susianto, 2015). An increase in income will have an effect on the improvement of health and family conditions and in turn will be determine the nutritional status. However, an increase in income or purchasing power often cannot overcome the effect of eating habits on effective nutrition improvement (Beck, 2015).

This study is very important to conduct since it can add information in the health sector, that is, it can be a description of the incidence of stunting and become input in the management of stunting using the right method to improve the quality of the development of under-five children.

The objectives of this study include:

a. To determine the description of the incidence of stunting among infants aged 24-59 months in the Work Area of Kadipaten Community Health Center, Majalengka District in 2019.

b. To determine the description of the socio-economic status of families among children aged 2459 months in the Work Area of Kadipaten Community Health Center, Majalengka District in 2019.

c. To determinethe relationship between socio-economic statusand the incidence of stunting among children aged 24-59 monthsin the Work Area of Kadipaten Community Health Center, Majalengka District in 2019.

\section{Literature Review}

\subsection{Under-five Cildren}

Under Five Years (toddler) is one of the periods of human age after an infant with an age range starting from two to five years, or the usual calculation of months is the age of 24-60 months.

\subsection{Nutritional Status}

Nutrition is the process wherein an organism uses normally consumed food through the processes of digestion, absorption, transportation, storage, metabolism and excretion of substances that are not used to maintain life, growth and normal function of organs, as well as produceenergy (Arisman, 2015).Nutritional status is a measure of the condition of a person's body which can be seen from the food consumed and the use of nutrients in the body (Almatsier, 2010).

\subsubsection{Assessment of Nutritional Status}

In Indonesia, the WHO-National Center for Health Statistics (WHO-NCHS) standard is often used or established to determine the classification of nutritional status which is used as a reference or as a comparison for the nutritional status and growth of individuals and communities in Indonesia (MoH of the Republic of Indonesia, 2017).

\subsubsection{Anthropometry}

One of direct assessment methodsfor nutritional status is by using anthropometry. Anthropometric measures are generally used to see an imbalance in protein and energy intake (Supariasa, 2015).

Height-for-age gives an indication of chronic nutritional problems as a result of a long-standing condition. Based on the characteristics, this index describes the nutritional status of the past-Table 1 (MoH of the Republic of Indonesia, 2015). 
Table 1. Nutritional Status with the Indicator of Height-for-age according to WHO Standard.

\begin{tabular}{ll}
\hline Z-Score & Category \\
\hline$\geq-2.0 \mathrm{SD}$ & Normal \\
$<-2.0 \mathrm{SD}$ & Short/Stunted \\
\hline
\end{tabular}

\subsection{Stunting}

\subsubsection{Definition of Stunting}

Chronic stunting or malnutrition is another form of growth failure. Another definition states that short and very short are the kinds of nutritional status based on the index of length-for-age or heightfor-age which is the equivalent of the terms stunted (short) and severely stunted (very short) (Wiyogowati, 2012).

Short refers to children who have a low height-for-age index. Short can reflect either normal variations in growth or deficits in growth. Stunting is a linear growth that fails to reach its genetic potential as a result of suboptimal health or nutritional conditions. A child is said having stunting if the height is below -2 SD based on the WHO standard (Anita, 2011).

\subsubsection{Factors Affecting Stunting}

Chronic malnutrition is caused by many factors, which are interrelated to one another. There are three main causes of stunting, namely unbalanced food intake, history of low birth weight, and history of disease (Wiyogowati, 2012).

a. Parental education. Education is the process of changing the attitude and behavior of a person or group of people in an effort to mature humans through teaching and training efforts. The level of parental education has a significant effect on the growth of under-five children. The level of education will affect food consumption by way of selecting foodstuffs (Rahayu, 2014).

b. Parents' occupation. Occupation is a need that must be done, especially to support life and the continuity of family's life (Nursalam, 2011). Occupationbecomes an important factor in determining the quality and quantity of food since it determines the income a person receives.

c. Economic status. Income is an important factor in determining the quality and quantity of food in a family. Economic status is everything related to economic action in fulfilling community needs such as clothes, food and shelter (Sarwono, 2014).

d. Age of the Child. Under-five is the most vulnerable age, because at this time they are at risk of infection so that children are at high risk of becoming malnourished. The characteristics of toddlers according to age are divided into two, namely children aged 1-3 years and preschool children aged 3-5 years (Arisman, 2015).

e. Gender of the Child. According to Hungu (2017) gender is the differences between a woman and a man biologically since a person is born. In the first year of life, male are more prone to malnutrition than female where the male body is bigger and requires a lot of nutritional intake, if it is not met for a long time, it can affect growth.

f. Birth Weight. Body weight is the most important measurement in newborns. Body weight is the result of increasing/decreasing quality of all the tissues in the body, including bones, muscles, fat, body fluids, and others. Body weight is used as the best indicator to determine the state of nutrition and child development (Trihono, 2015).

g. Birth Length. Inadequate maternal nutritional intake before pregnancy causes growth problems in the fetus and can cause babies to be born with short birth lengths. The baby is born with a normal birth length, if the birth length is $48-52 \mathrm{~cm}$ and it is said to be short if $\leq 48 \mathrm{~cm}$.

h. Exclusive breastfeeding. Breast milk contains protective substances and nutrients, breast milk ensures a good nutritional status of the baby and decreases the likelyhood of morbidity and mortality of children. Some studies found that breast milk protected babies and children from infectious diseases, such as diarrhea, respiratory infections. Colostrum in breast milk contains 10-17 times more immune substances than mature milk (Kemenkes RI, 2014). 
i. $\quad$ Parenting

Dietary Parenting

Dietary parenting is a way of eating a person or group of people in choosing food and eating it in response to physiological, cultural and social psychological influences (Sarwono, 2014).

The factors that need to be considered for proper eating arrangements are age, weight, condition of the mouth as a means of receiving food, eating habits, likes/dislikes, and the child's tolerance for the food given.

Healthcare Parenting

Healthcare practices are several things that performed to maintain the health status of the child, keep away and prevent disease and can cause a decline in the child's health condition which will affect the child's nutritional status (Sarwono, 2014).

j. Immunization Status. Providing immunization to children has an important goal to reduce the risk of morbidity and mortality of children due to diseases that can be prevented by immunization (Indonesian Pediatric Society, 2015). Immunization status of children is an indicator of contact with health services. The implementation of immunization activities is expected to have a positive effect in improving long-term nutritional status (Yimer, 2000).

k. History of Infectious Disease. Infectious diseases are related to low nutritional status. The relationship between malnutrition and infectious diseases can be explained through the body's defense mechanism. In malnourished under-fives with low energy and protein intake, the body's ability to form the new protein is decreased. Then the body will be vulnerable to infection due to disruption of the formation of cellular immunity (Desyanti \& Nindya, 2017).

\subsubsection{Effect of Stunting}

Nutritional problems, especially stunting among under-five children, can hinder children's development, along with negative impacts that will last in the next life, such as intellectual decline, susceptibility to non-communicable diseases, decreased productivity, the inceidence of poverty and the risk of having low birth weightbaby (Nimah \& Nadhiroh, 2015).

\section{Methods}

A quantitative study was conducted with cross sectional design. This study aims to determine the relationship between socio-economic statusand the incidence of stunting among children aged 24-59 months in the Work Area of Kadipaten Community Health Center, Majalengka District in 2019.

The population in this study was parents andchildren aged 24-59 months in the WorkArea of Kadipaten CHC, Majalengka District. The samples in this study were 328children aged 24-59 monthstaken with simple random sampling technique. The study data were in the form of primary data derived from anthropometric measurements of children and this study also used a study instrument in the form of a questionnaire containing questions to be asked to respondents.

Data analysis in this study consisted of Univariate Analysis for the analysis of each study variable with a frequency distribution and Bivariate analysis which was carried out on two variables which were expected to be related to each other using the chi square test. After obtaining studypermission, the next step was conducting the study by emphasizing ethical issues including Inform Consent, Anonymity, Confidentiality and Beneficence.

\section{Results}

\subsection{Description of the incidence of stunting among children aged 24-59 months}

The description of the nutritional status of children aged 24-59 months in the work area of Kadipaten CHC, MajalengkaDistric used the Height-for-age index (H/A) which was classified into 2, namely stunting and normal. 
Table 2. Frequency Distribution of the Incidence of Stunting among

Children Aged 24-59 Month.

\begin{tabular}{ccc}
\hline Nutritional Status & Frequency & Percentage (\%) \\
\hline Stunting & 37 & 11.3 \\
Normal & 291 & 88.7 \\
Total & 328 & 100.0 \\
\hline
\end{tabular}

Based on Table 2, it can be seen that 37 children aged 24- 59 (11.3\%) months in the Work Area of Kadipaten CHC, Majalengka District in 2019 had stunting and the remaining 291 children (88.7\%) had normal nutritional status. This showed that a small proportion (11.3\%) of children aged 24-59 months in the Work Area of Kadipaten CHC in Majalengka District in 2019 experienced stunting.

4.2. Description of Family Economic Status among Children Aged 24-59 Months

Family economic status among under-five children in the Work Area of Kadipaten CHC, Majalengka District, in 2019 was divided into 2 categories, namely low income ( $\leq$ Rp. 1,658,514) and high income (>Rp. 1,658,514,-). This category of family economic status is based on the 2019 Regional Minimum Wage for Majalengka District. The frequency distribution of family economic status can be seen in Table 3.

Table 3. Frequency Distribution of Family Economic Status among Children Aged 24-59 Months.

\begin{tabular}{ccc}
\hline Family Economic Status & Frequency & Percentage (\%) \\
\hline Low & 120 & 36.6 \\
High & 208 & 63.4 \\
Total & 328 & 100.0 \\
\hline
\end{tabular}

Table 3 shows that 120 children aged 24-59 months (36.6\%) in the Work Area of Kadipaten CHC, Majalengka District in 2019 had low family economic status and 208 (63.4\%) children had high economic status. Thus it was found that less than half (36.6\%) of children aged 24-59 months in the Work Area of Kadipaten CHC, Majalengka District in 2019 had low family economic status.

4.3. Relationship between Family Socio-Economic Status and the Incidence of Stunting among Children Aged 24-59 Months

Among children aged 24-59 months in the Work Area of Kadipaten CHC, Majalengka District in 2019, 18.3\% had low socio-economic status below the Regional Minimum Wage and sstunting. Meanwhile, $7,2 \%$ childrenhad high socioeconomic status/above the Regional Minimum Wage and experienced stunting (Table 4). This indicated that the proportion of under-five children with a socioeconomic status below the Regional Minimum Wage and experienced stunting was higher than those with a high socioeconomic status/above the Regional Minimum Wage and experienced stunting.

Table 4. Proportion Distribution of the of the Relationship between Family Socio-

Economic Status and the Incidence of Stunting among Children aged 24-59 Months.

\begin{tabular}{|c|c|c|c|c|c|c|c|}
\hline \multirow{3}{*}{$\begin{array}{l}\text { Socio-Economic } \\
\text { Status }\end{array}$} & \multicolumn{6}{|c|}{$\begin{array}{c}\text { Nutritional Status of Children Aged 24-59 } \\
\text { Months }\end{array}$} & \multirow[b]{3}{*}{ p-value } \\
\hline & \multicolumn{2}{|c|}{ Stunting } & \multicolumn{2}{|c|}{ Normal } & \multicolumn{2}{|l|}{ Total } & \\
\hline & $\mathbf{n}$ & $\%$ & $\mathrm{n}$ & $\%$ & $\mathbf{n}$ & $\%$ & \\
\hline $\begin{array}{l}\text { Low/Below Regional } \\
\text { Minimum Wage }\end{array}$ & 22 & 18.3 & 98 & 81.7 & 120 & 100 & \multirow{3}{*}{0.02} \\
\hline $\begin{array}{l}\text { High/Above Regional } \\
\text { Minimum Wage }\end{array}$ & 15 & 7.2 & 193 & 92.8 & 208 & 100 & \\
\hline Total & 37 & 11.3 & 291 & 88.7 & 328 & 100 & \\
\hline
\end{tabular}

The results of the Chi Square statistical test obtained a p value $=0.02(<0.05)$, so it can be said that H0was rejected or there was a significant relationship between the family socio-economic status and the incidence of stunting in the Work Area of Kadipaten CHC, Majalengka District in 2019. 


\section{Discussion}

\subsection{Description of the Incidence of Stunting among Children Aged 24-59 months}

The results showed that a small proportion (11.3\%) of children aged 24-59 months in the Work Area of Kadipaten CHC, Majalengka District in 2019 experienced stunting.

Chronic stunting or malnutrition is another form of growth failure. Another definition states that short and very short are the kinds of nutritional status based on the index of length-for-age or heightfor-age which is the equivalent of the terms stunted (short) and severely stunted (very short) (Wiyogowati, 2012).

The results of the Basic Health Research in 2018 showed that the prevalence of stunting in the national scope was $30.8 \%$, consisting of a stunting prevalence of $19.3 \%$ and a very short prevalence of 11.5\%. Meanwhile in 2017, the prevalence of stunting in Indonesia was $29.0 \%$, consisting of a stunting prevalence of $19.8 \%$ and a very short prevalence of $9.8 \%$. This indicated that the incidence of stunting among under-five children in Indonesia in 2017-2018 increased by 1.8\% and became a serious public health problem because the prevalence of stunting in Indonesia was in the 30-39 percent range (Indonesian Ministry of Health, 2019). Whereas in West Java Province in 2018, 11.70\% under-five children who experienced very short stunting and $19.40 \%$ were short and in $20178.40 \%$ children experienced very short stunting and $20.80 \%$ were short (West Java Provincial Health Office, 2018).

Based on data derived from the Majalengka District Health Office in 2019, out of a total of 88,139 toddlers, 3,905 under-five children (4.43\%) experienced stunting and 737 (0.84\%) were very short children. Whereas in 2018, there were 1,958 toddlers (2.19\%) who experienced stunting. This meant that the incidence of stunting among under-five children in Majalengka District increased by $2.24 \%$, from $2.19 \%$ to $4.43 \%$ in 2018 (Majalengka District Health Office, 2019).

According to data, stunting was not only existing in the area of Kadipaten CHC, it turned out that stunting was a major public health problem in almost all provinces in Indonesia. According to the Indonesian Ministry of Health (2018) when compared to the limit for non-public health problems according to WHO, the incidence of stunting in the Work Area ofKadipaten CHC was 36.7\% and it has exceeded the universally agreed cut-off threshold.

In this study, it was found that $36.7 \%$ of children aged 24-59 months in Kadipaten CHC, Majalengka District were stunting. The incidence of stunting in the work area of Kadipaten CHC has exceeded the average stunting rate in Majalengka District, so it requires more attention to reduce the incidence.

The incidence of stunting in the work area of Kadipaten CHCin Majalengka District can be categorised as a public health problem that needs to be managed together with the local CHC and the government, in this case the Majalengka District Health Office. There is a need for Government policies that contribute to reducing the incidence of stunting in particular, one of which is by conducting routine evaluations of nutritional status monitoring in the local area.

\subsection{Description of Family Economic Status of Children Aged 24-59 months}

The results showed that less than half (36.6\%) of thefamilies of children aged 24-59 months in the Work Area of Kadipaten Community Health Center, Majalengka District in 2019 had a low economic status. Economic status can be described by the income earned by the family. Low income can be due to the income earned has not reached the predetermined Regional Minimum Wage, adn it may result to low income so that the family's needs cannot be met. Most of the respondents had livelihoods as casual daily laborers so that their income in a month is barely enough. This condition causes nutritional intake to be hampered because of their limitations in serving nutritious and diverse foods.

The result of the family income in this study showed a lower level than what was found in the study conducted by Nadiyah (2015) in the Provinces of Bali, West Java, and East Nusa Tenggara which showed that $70.5 \%$ of families hada low income as well as in the study conducted by Setiawan, et al., (2018), in the Work Area of AndalasCHC, East Padang District, Padang City, which showed that 54.5\% families had low income.

According to Winardi (2015) income is the revenue in the form of money or other material that can be achieved from the use of production factors in a certain period. Based on this understanding, it can be concluded that family income is the income of the family in each month which will describe the condition or socioeconomic status of the family. 
Family income is the main determinant related to food quality. If the family income increases, the quality of the side dishes will also increase. . It cannot be denied that family income will determine the dishes served for the family daily, both regarding the quality and quantity of food (Susianto, 2015). According to Beck (2015) an increase in income will have an effect on improving the health and condition of the family and subsequently relatedto the incidence of stunting. However, increases in income or purchasing power often cannot outweigh the effect of eating habits on effective nutrition improvement.

There were still families with low income, so health workers need to make visits to mothers, especially those with low incomes, to provide motivation and guidance to mothers about stunting prevention through weighing the children at the Integrated Healthcare Service Postregularly. Women with under-five children should bring their children regularly to the Integrated Healthcare Service Post and provide nutritious and balanced meals for their children.

Kadipaten CHC Unit should be able to work with related agencies to provide skills training for the community. It is espected that the skills possessed by the community will be able to create new businesses that support an increase in family income which will affect the pattern of family nutrition fulfillment.

5.3. Relationship between Family Socio-Economic Status and the Incidence of Stunting among Children Aged 24-59 Months

The results showed that there was a significant relationship between the socio-economic status of the family and the incidence of stunting in the Work Area of Kadipaten CHC, Majalengka District in 2019.This can be due to low income causes family limitations in serving nutritious food for their children so that their children had a greater chance of experiencing stunting.

The existence of a significant relationship between low family economic status and the incidence of stunting among under-five children was also shown in the study conducted by Hartoyo, et al., (2002) which showed that low-income families usually had low self-confidence to participate in health activitiessuch as posyandu and guidance for the family of under-five children. Therefore, they have a higher risk of developing malnutrition.

The result of this study is in line with the results of study conducted by Nadiyah (2015) in the Provinces of Bali, West Java, and East Nusa Tenggara which showeda positive and significant relationship between low income and stunting among children aged 0-23 months ( $\mathrm{r}=0.003)$. The result of this study is also in accordance with study conducted by Setiawan (2018) in the Work Area of Andalas CHC, East Padang District, Padang City, which showed that there was a significant relationship between the level of family income and the incidence of stunting $(r=0.003)$.

The resultof this study is not in line with the theory that family income is the main determinant related to food quality. If the family income increases, the quality of the side dishes will also increase. It cannot be denied that family income will determine the dishes served for the family daily, both regarding the quality and quantity of food (Susianto, 2015). According to Beck (2015), an increase in income will have an effect on the improvement of health and andeconomic condition of the family and it subsequently related to the incidence of stunting. However, an increase in income or purchasing power often cannot overcome the effect of eating habits on effective nutrition improvement.

The result of this study is not in line with the theory proposed by Kristianti and Parjo (2015), that families with more income are likely to be good and even excessive in meeting food needs, on the other hand, families with limited income are likely to be less likely to meet food needs, especially to meet nutritional needs.The higher the family income, the better the family's ability to fulfill their family nutrition, conversely, the lowerthe family income, the more difficult it will be to fulfill the family's nutritional needs. Difficulty in fulfilling nutrition leads the children to be malnourished and can also result in poor children's growth that is shorter than normal (Arisman, 2015).

Low income is one of the factors associated with stunting.Therefore, healthcare workers need to make regular visits to mothers, especially those with low incomes, to provide motivation and guidance to mothers about stunting prevention through weighing the children at the Integrated Healthcare Service Post regularly. Furthermore, it is expected that Kadipaten CHC will cooperate with Government agencies, in particular the District Government of Kadipaten, to provide skills training to families with a history of low economic status or low income families, in order to provide trainingskills for the community.It is expected that through skills training, many parents of under-five children have jobs or are able to increase income through entrepreneurship. Thus, it will affect the pattern of family nutrition fulfillment. 


\section{Conclusions}

Based on the results and discussion of the study on "Relationship between Family Socio-Economic Status and the Incidence of Stunting among Children Aged 24-59 Months in the Work Area of Kadipaten Community Health Center, Majalengka District in 2019", it can be concluded that:

a. A small proportion (11.3\%) of children aged 24-59 months in the Work Area of Kadipaten CHC, Majalengka District in 2019 experienced stunting.

b. Less than half (36.6\%) of the familiesamong children aged 24-59 months in the Work Area of Kadipaten CHC, Majalengka District in 2019 had a low economic status.

c. There was a significant relationship between familysocio-economicstatus and the incidence of stuntingamong childrenaged 24-59 Months in the Work Area of Kadipaten Community Health Center, Majalengka District in 2019 with a p value $=0.02$.

\section{Recommendations}

a. Government

The local government needs to conduct skills training for parents of under-five children, especially parents with low socio-economic status. Skills delivered can be in the form of making works of art, utilizing waste into useful goods or other skills that are adapted to regional potential. It is expected that through skills training, many parents of under-five children have jobs or are able to increase income through entrepreneurship. Thus, it will affect the pattern of family nutrition fulfillment.

b. Kadipaten CHC Unit

In an effort to prevent the incidence of stunting, healthcare workers should work together with cadres to carry out Integrated Healthcare Service Post activities regularly every month, motivate mothers to bring their children to be weighed to the Integrated Healthcare Service Post every month, providecounseling to mothers about nutrition in an effort to prevent the incidence of stunting by using methods that are more attractive and easy to understand, such as using leaflets or posters.

c. Family/The Mother of the Under-five Children

Mothers and families shou; d be active in Integrated Healthcare Service Post activities. Mothers or families with babies should provide proper nutrition according to their needs, and monitor their children's growth and development regularly by weighing the children at the Integrated Healthcare Service Post.

d. Further Researchers

There are many factors related to the incidence of stunting among under-five children, either directly or indirectly. It is expected that further studies can be conducted by including various variables other that those used in this study, such as energy and protein intake among under-five children.

\section{Acknowledgment}

This research was funded by the Simlitabmas Research Grant from the DIKTI DPRM with Contract Number: 092 / SP2H / AMD / LT-MONO / LL4 / 2020. There was a lot of support for the authors during the preparation of this study. Thus, in this opportunity, the authors would like to express deepest gratitude to:

1. Prof. Uman Suherman, as the Head of LLDIKTI Region IV.

2. H. Satmaja, BA., as the Head of the Imam Bonjol Education Foundation (YPIB) Majalengka.

3. WawanKurniawan, SKM.,M.Kes., as the Head of STIKes YPIB Majalengka.

4. H. AnangSetiana, SKM., MKM., as the Head of Kadipaten Community Health Center Unit

5. Heni, S.Kep.,Ners., M.Kep., as the Head of the Majalengka Nursing Profession Study Program.

6. Yeti Yuwansyah, S.ST.,M.Kes., as the Head of Institute of Reasearh and Community Service of STIKes YPIB Majalengka.

\section{References}

Almatsier, S. (2015). Gizi Seimbang dalam Daur Kehidupan. Jakarta: Gramedia Pustaka Utama.

Anita (2011). Dukungan keluarga dan kejadian stunted pada anak balita di Kabupaten Simeulue. Thesis. Universitas Gadjah Mada.

Aridiyah, F. O., Rohmawati, N. \& Ririanty, M. (2015). Faktor-faktor yang Mempengaruhi Kejadian Stunting pada Anak Balita di Wilayah Pedesaan dan Perkotaan (The Factors Affecting Stunting on Toddlers in Rural and Urban Areas). Pustaka Kesehatan, 3(1): 163-170

Arisman. (2015). Gizi Dalam Daur Kehidupan: Buku Ajar Ilmu Gizi. Jakarta: Buku Kedokteran EGC. 
Beck. (2015). Ilmu Gizi dan Diet, Hubungannya dengan Penyakit-penyakit untuk Perawat dan Dokter. Yogyakarta: Andi Publisher.

Desyanti, C. \& Nindya, T.S. (2014). Hubungan Riwayat Penyakit Diare dan Praktik Higiene dengan Kejadian Stunting pada Balita Usia 24-59 Bulan di Wilayah Kerja Puskesmas Simolawang, Surabaya. Amerta Nutrition 1(3): 243-251

Hartoyo, Hastuti, D., Briawan D, Setiawan, B. \& Yuliati L. N. (2002). Pengembangan model tumbuh kembang anak terpadu di kota Bogor. Bogor: Kerjasama jurusan gmsk dengan PLAN international.

Hungu. (2007). Demografi Kesehatan Indonesia. Grasindo.

Ikatan Dokter Anak Indonesia. (2015). Pencegahan dan Penananganan Balita Stunting. www.idai.or.id, accessed on March 14, 2020.

Kadipaten CHC Unit. (2020). Data Stunting pada Balita Tahun 2019 di UPTD Puskesmas Kadipaten.Majalengka: Lemahsugih CHC Unit.

Kristianti, D., Suriadi., \& Parjo. (2015). Hubungan antara karakteristik Pekerjaan ibu dengan status gizi anak usia 46 tahun di TK Salomo Pontianak. Jurnal Kebidanan Pontianak.

Majalengka Health Office. (2019). Profil Kesehatan Kabupaten Majalengka Tahun 2018. Majalengka: Majalengka Health Office.

Kementerian Kesehatan RI, (2014). Pedoman Gizi Seimbang. Kementerian Kesehatan RI: Direktorat Bina Gizi.

Ministry of Health of the Republic of Indonesia. (2015). Standar Antropometri Penilaian Status GiziAnak. Jakarta: Directorate of Nutrition Development.

Ministry of Health of the Republic of Indonesia. (2017). Indonesian Health Profile Kesehatan of 2016. Jakarta: Ministry of Health of the Republic of Indonesia.

Ministry of Health of the Republic of Indonesia. (2019).Basic Health Research of 2018. Jakarta: Ministry of Health of the Republic of Indonesia.

Mukti. (2019). Faktor-faktor yang Berhubungan dengan Kejadian Balita Stunting di Wilayah Kerja UPTD Puskesmas Sindang Kabupaten Majalengka Tahun 2019. Majalengka: STIKes YPIB Majalengka.

Nadiyah. (2015). Faktor Risiko Stunting Pada Anak Usia 0-23 Bulan Di Provinsi Bali, Jawa Barat, Dan Nusa Tenggara Timur. Jurnal Gizi dan Pangan, 9(2): 125-132.

Ni'mah, K. \& Nadhiroh, S. R. (2015). Faktor yang berhubungan dengan kejadian stunting pada balita. Media Gizi Indonesia, 10(1): 13-19

Nursalam. (2011). Konsep dan penerapan metodologi penelitian ilmu keperawatan. Salemba Medika.

Rahayu, A. \& Khairiyati, L. (2014). Risiko pendidikan ibu terhadap kejadian stunting pada anak 6-23 bulan, Penel Gizi Makan 37(2): 129-136.

Sarwono. (2015). Ilmu Sosial dan Psikologi. Jakarta: SalembaMedika.

Setiawan, E., Machmud, R. \& Masrul, M. (2018).Faktor-Faktor yang Berhubungan dengan Kejadian Stunting pada Anak Usia 24-59 Bulan di Wilayah Kerja Puskesmas Andalas Kecamatan Padang Timur Kota Padang Tahun 2018. Jurnal Kesehatan Andalas, 7(2): 275-284

Sudiaoetama. (2015). Ilmu Gizi untuk Mahasiswa dan Profesi. Jakarta: Dian Rakyat.

Supariasa, E. (2015).Penilaian Status Gizi. Jakarta: BukuKedokteranEGC.

Susianto. (2015). The Miracle of Vegan. Jakarta: Qanita.

Trihono, T.,Atmarita, A., Tjandrarini, D. H., Irawati, A., Nurlinawati, I., and Utami, N. H., \& Tejayanti, T. (2015). Pendek (Stunting) di Indonesia, Masalah dan Solusinya. Lembaga Penerbit Badan Litbangkes,

West Java Provincial Health Office. (2018). Derajat Kesehatan Provinsi Jawa Barat. Bandung: West Java Province Health Office.

Winardi, T. (2015). Strategi Pemasaran. PT. Gramedia Pustaka Utama.

Wiyogowati C. (2012). Kejadian stunting pada anak berumur dibawah lima tahun( 0 - 59 tahun) di provinsi papua barat tahun 2010. Faculty of Public Health Sciences.[ diunduh 1 februari 2018] available at: http://lib.ui.ac.id/file?file=digital/20288982-S-Citaningrum\%20Wiyogowati.pdf

Yimer, G. (2000). Malnutrition Among Children in Southern Ethiopia: Levels and Risk Factors. Ethiop. J. Health Dev, 14(3): 283-292. 